\title{
Scanning Electron Microscopic Study of the Tongue in the Oriental Scops Owl (Otus scops)
}

\author{
By \\ Shoichi EMURA ${ }^{1}$, Toshihiko OKUMURA ${ }^{2}$ and Huayue CHEN ${ }^{3}$ \\ ${ }^{1}$ Nursing Course, Gifu University School of Medicine, Gifu 501-1193, Japan \\ ${ }^{2}$ Laboratory of Technology, Gifu University School of Medicine, Gifu 501-1194, Japan \\ ${ }^{3}$ Department of Anatomy, Gifu University Graduate School of Medicine, Gifu 501-1194, Japan \\ - Received for Publication, November 17, 2008 -
}

Key Words: Oriental scops owl, Lingual papillae, Connective tissue core, SEM

\begin{abstract}
Summary: The dorsal lingual surface of an adult owl (Otus scops) was examined by scanning electron microscopy. The tongue of the adult owl was about $1 \mathrm{~cm}$ long. Three parts were distinguished in the dorsal surface of the tongue: the apex, the body and the root of the tongue. The conical region between the lingual apex and lingual root was very wide area. The conical papillae of the lingual body were inclined toward the posterior of the tongue. At low magnification of scanning electron microscopy, the desquamated cells were observed in the entire dorsal surface of the lingual apex. The connective tissue cores of the epithelium of the lingual apex showed the rod-shaped protrusions. The border between the lingual apex and body was clear and the small conical papillae were observed in the lingual body. The small and large conical papillae were observed on the lingual body. The many openings of the lingual glands existed in the lingual body and lingual root.
\end{abstract}

The studies on the structure of the tongue in birds have been conducted on a small number of species, i.e. chicken, African grey parrot, Middendorff's bean goose, white tailed eagle, cormorant, black kite, common pheasant, tree sparrow, peregrine falcon and common kestrel, northern goshawk, swan and Ural owl (Iwasaki and Kobayashi, 1986; Homberger and Brush, 1986; Iwasaki et al., 1997; Jackowiak and Godynicki, 2005; Jackowiak et al., 2006; Emura, 2008a; Emura, 2008b; Emura et al., 2008a; Emura et al., 2008b; Emura et al., 2008c; Emura, 2008c; Emura and Chen, 2008). The results of morphological studies conducted so far indicate a close correlation of the shape of the tongue with the method of food intake and the type of food, and habitat.

However, no scanning electron microscopic study of the tongue of the Oriental scops owl has been carried out. The purpose of this study is, therefore, to examine threedimensionally the dorsal lingual surface of the Oriental scops owl, in order to compare the results with those previous reports in other birds.

\section{Materials and Methods}

The tongue of an adult Oriental scops owl (Otus scops) of the family Strigidae was used in this study. The tongue was fixed in $10 \%$ formalin. The tongue was cut in half with a razor blade, post-fixed with $1 \%$ osmium tetroxide for $1 \mathrm{~h}$. Thereafter, the specimen was dehydrated through graded series of acetone and critical-pointdried. To show the three-dimensional connective tissue structure of the lamina propria of the mucosa, the sample was washed in distilled water after formalin fixation and macerated in $3.5 \mathrm{~N} \mathrm{HCl}$ at room temperature for 5 days. After maceration tissue was washed in the distilled water and post-fixed in $1 \%$ osmium tetroxide for $1 \mathrm{~h}$, and dehydrated in a series of acetone and critical point dried. All specimens were sputtered with Pt-Pd before being examined under SEM (Hitachi S-3500N, Tokyo, Japan) at an accelerating voltage of $15 \mathrm{kV}$.

\section{Results}

The tongue of the adult owl (Otus scops) is about 1 $\mathrm{cm}$ long. Three parts are distinguished in the dorsal surface of the tongue: the apex, the body and the root of the tongue (Fig. 1). The conical region between the lingual apex and lingual root is very wide area (Fig. 1). The conical papillae of the lingual body are inclined toward 


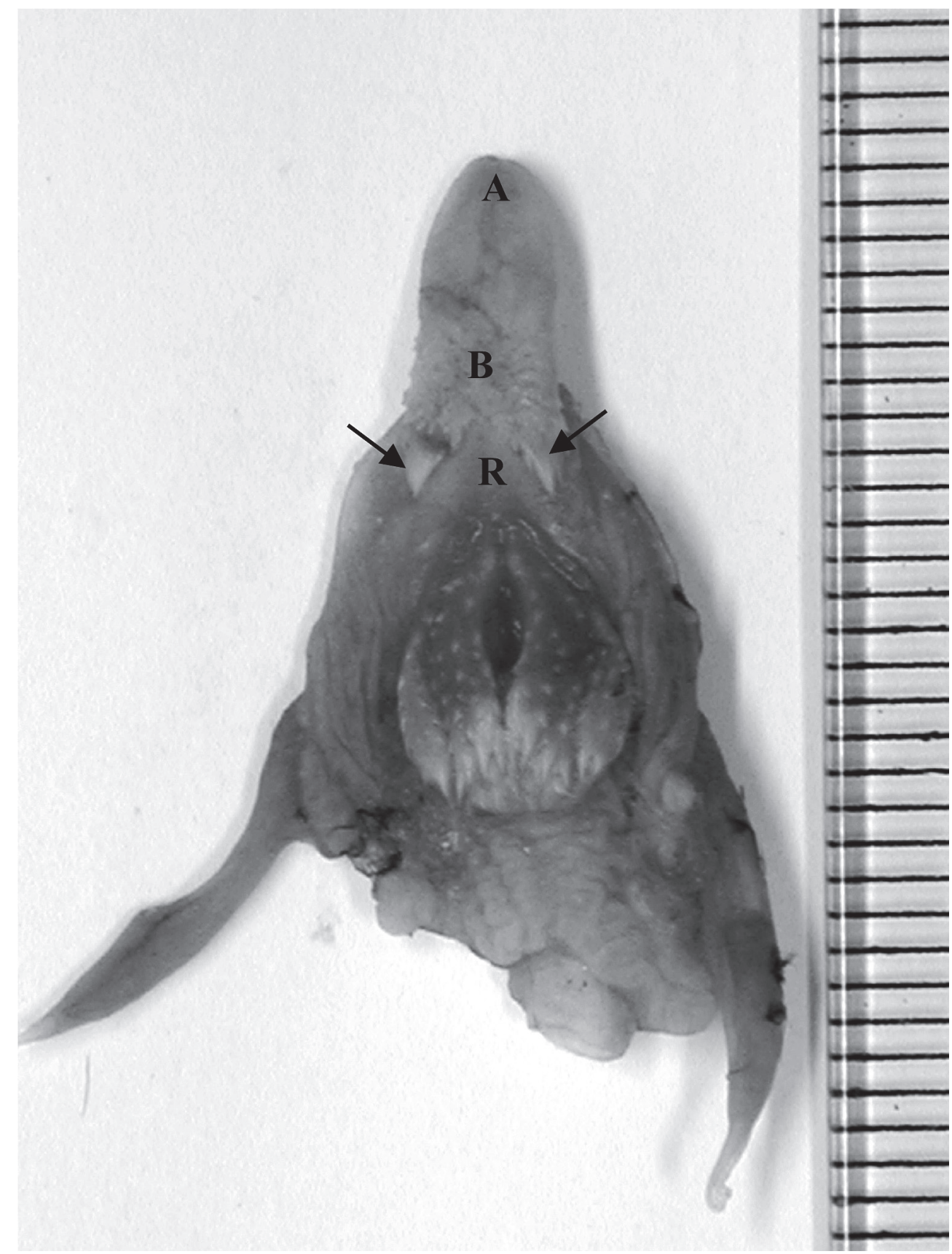

Fig. 1. Macrograph of an oriental scops owl tongue. Three parts are distinguished in the tongue: lingual apex (A), lingual body (B) and lingual root $(\mathrm{R})$. Arrows $=$ Conical papillae. Scale $=1 \mathrm{~mm}$.

the posterior of the tongue (Figs. 1 and 4). At low magnification of scanning electron microscopy, the desquamated cells are observed in the entire dorsal surface of the lingual apex (Fig. 2a). The connective tissue cores of the epithelium of the lingual apex show the rod-shaped protrusions (Fig. 2b). The border between the lingual apex and body is clear and the small conical papillae are observed in the lingual body (Fig. 3). The small and large conical papillae are observed on the lingual body (Figs.
$4 a, b)$. The many openings of the lingual glands exist in the lingual body and lingual root (Figs. 3 and 4). The conical papillae and lingual root show the flat surface (Fig. 4). On the surface of the conical papillae and lingual root after removing the epithelium, a pattern of low connective tissue ridges is observed (Fig. 4). 

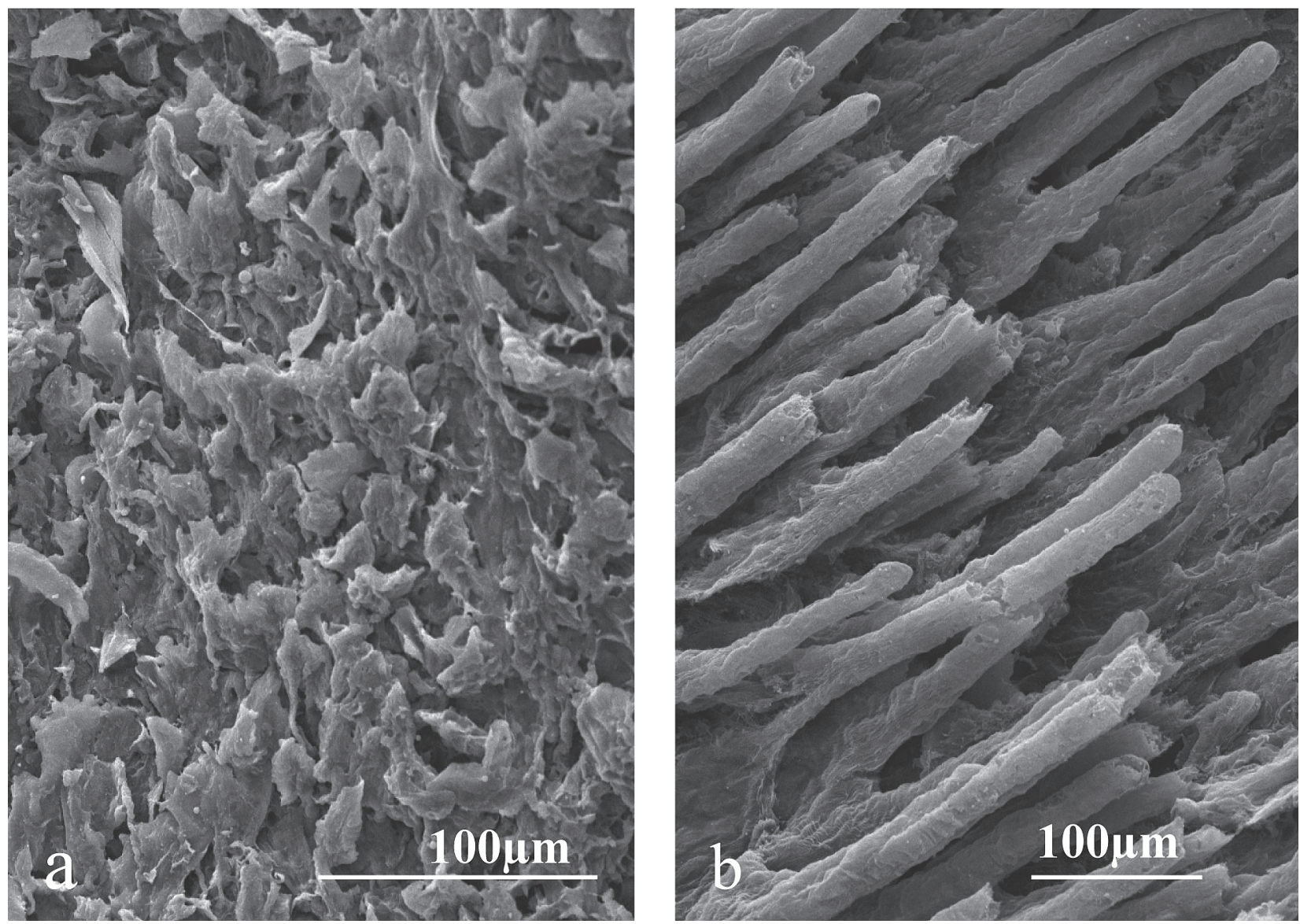

Fig. 2. Scanning electron micrographs of the dorsal surface of the lingual apex. (a) Showing the desquamated cells. (b) The connective tissue cores of the epithelium of the lingual apex show the rod-shaped protrusions.

\section{Discussion}

All birds are adapted to their different environments with respect to food sources. Reflecting their different lifestyles, birds have different feeding habits, with corresponding differences in the structures of their bills and tongues.

The many processes were observed densely distributed over the apex and body of the dorsal lingual surface in some birds (Iwasaki and Kobayashi, 1986; Jackowiak and Godynicki, 2005; Emura, 2008a; Emura, 2008b; Emura et al., 2008a; Emura et al., 2008b; Emura et al., 2008c; Emura, 2008; Emura and Chen, 2008). This result was the same as those of the lingual apices in the Oriental scops owl. The connective tissue cores of the epithelium of the lingual apex showed the saw-shaped protrusions in the peregrine falcon and the thread-shaped protrusions in the common kestrel (Emura et al., 2008b). In this study, that of the lingual apex showed the rod-shaped protrusions.

In the marginal region between the anterior and posterior parts of the tongue of the chicken, a close array of giant conical papillae was observed, arranged transversely in a row (Iwasaki and Kobayashi, 1986). On the tongue of the Middendorff's bean goose, giant conical papillae were located in a transverse row between the lingual body and the lingual radix (Iwasaki et al., 1997). At a point approximately $2 / 3$ of the length of the tongues in the white tailed eagle, black kite and northern goshawk, between the body and the root of the tongue there were large conical papillae, the apices of which were pointed towards the posterior part of the tongue (Jackowiak and Godynicki, 2005; Emura, 2008a; Emura et al., 2008c). In the tongues of the Ural owl, the conical region between the lingual apex and lingual root was a very wide area (Emura and Chen, 2008). In this study, the conical region between the lingual apex and lingual root was a very wide area.

Jackowiak and Godynicki (2005) reported that the orifices of the anterior glands were situated on the lateral surfaces of the posterior part of the lingual body, whereas the posterior lingual glands open on the entire surface of the lingual root. In the mammals, some openings of the glandular ducts at the dorsal surfaces of the conical papil- 


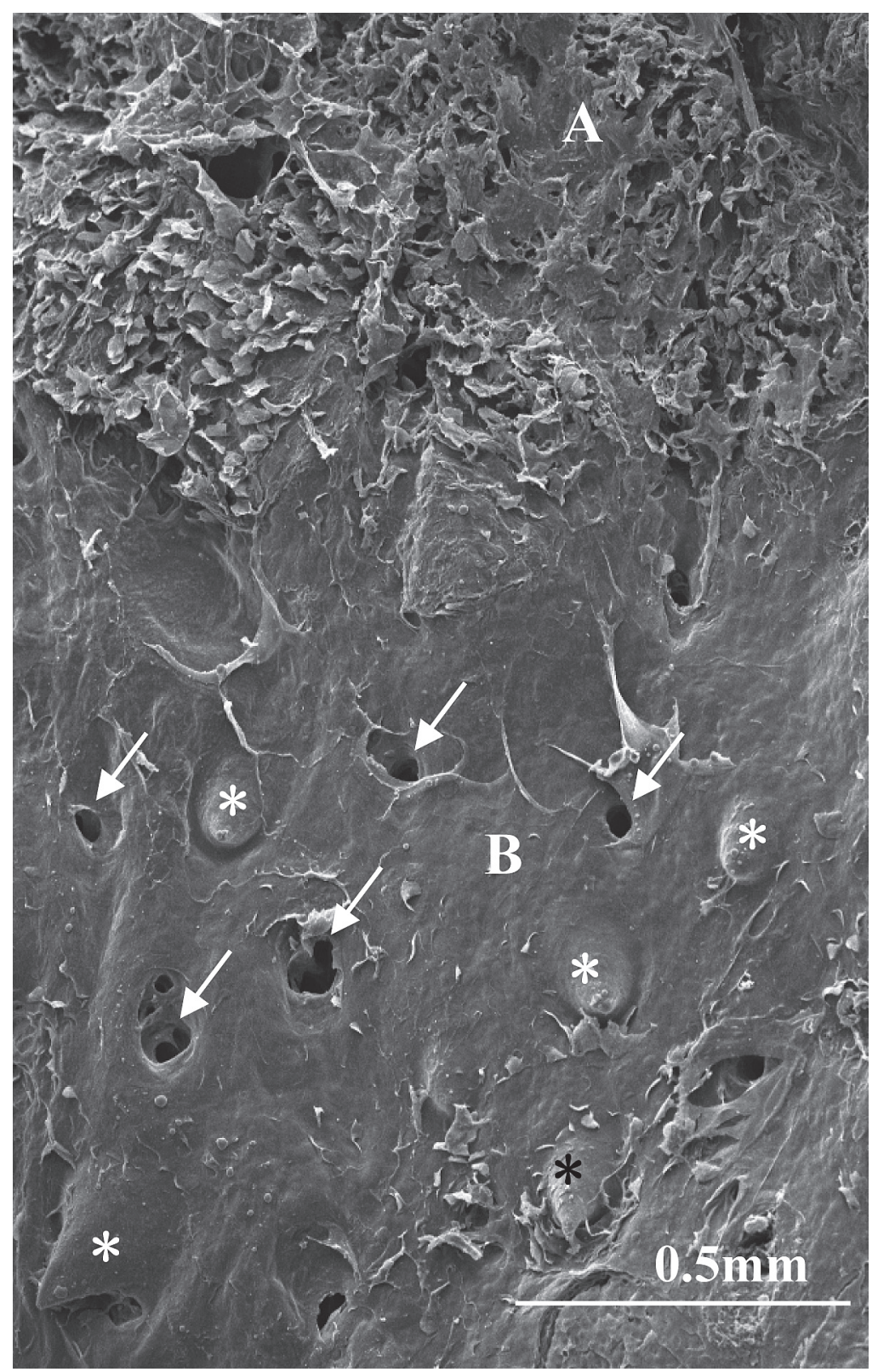

Fig. 3. The border between the lingual apex (A) and body (B) is clear. Arrows = openings of the lingual glands. Asterisks = small conical papillae.

lae of the lingual radix were observed in the tiger (Emura et al., 2004), fox (Jackowiak and Godynicki, 2004) and mole (Jackowiak, 2006). In the tongues of the peregrine falcon and common kestrel, the many openings of the lingual glands existed in the entire surfaces of the lingual body and lingual root (Emura et al., 2008b). However, the openings of the lingual glands in the mammals are a small number than that of the white tailed eagle, peregrine falcon and common kestrel. The many openings of the lingual glands in the lingual body and lingual root were observed in the Oriental scops owl as well as that of the Ural owl (Emura and Chen, 2008).

The white tailed eagle feeds mostly on fish and the Ural and Oriental owls feed on small animal. Furthermore, in the white tailed eagle the crest of the conical papillae found in the lingual body was sites aiding in the transfer of the swallowed food towards the oesophagus and at the same time preventing its regurgitation (Jackowiak and Godynicki, 2005). In the Ural and Oriental owls, there were observed not only the crest but also the many conical papillae on the lingual body. Therefore, the differences in the structures of the tongues in the white 

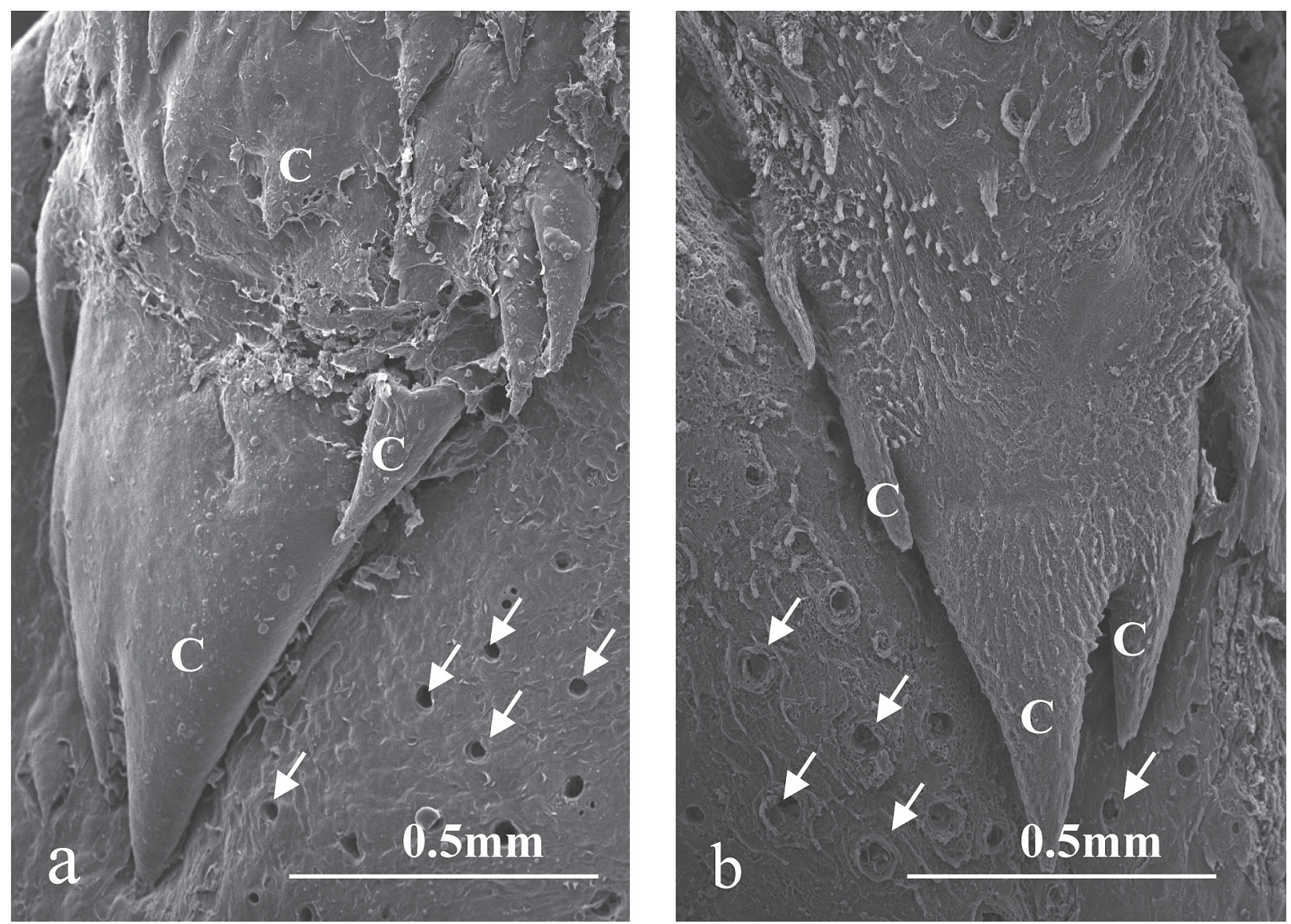

Fig. 4. The many openings (arrows) of the lingual glands exist in the lingual root. (a) The conical papillae (C) and lingual root show the flat surface. (b) On the surface of the conical papillae (C) and lingual root after removing the epithelium, a pattern of low connective tissue ridges is observed.

tailed eagle and Oriental scops owl may be by reason of the different feeding habits. In conclusion, the morphological characteristics of the tongues in the Ural and Oriental owls were similar to each other.

\section{Acknowledgements}

The authors would like to express their most sincere thanks to Dr. T. Okano of Wild Animal Rescue Center of Gifu University for their assistance in preparing the material for this study.

\section{References}

1) Emura S. SEM studies on the lingual papillae and their connective tissue cores of the black kite (Milvus migrans) (in Japanese). Medicine and Biology 2008a; 152:43-47.

2) Emura S. SEM studies on the lingual papillae and their connective tissue cores of the common pheasant (Phasianus colchicus) (in Japanese). Medicine and Biology 2008b; 152:129-133.
3) Emura S. SEM studies on the connective tissue cores of the lingual papillae of swans (in Japanese). Medicine and Biology 2008c; 152:4379-385.

4) Emura $\mathrm{S}$ and Chen H. Scanning electron microscopic study of the tongue in the owl (Strix uralensis). Anat Histol Embryol 2008; 37:475-478.

5) Emura S, Hayakawa D, Chen $H$ and Shoumura S. Morphology of the lingual papillae in the tiger. Okajimas Folia Anat Jpn 2004; 81:39-44.

6) Emura S, Okumura T and Chen H. SEM studies on the lingual papillae and their connective tissue cores of the tree sparrow (Passer montanus) (in Japanese). Structure and Function 2008a; 7:7-12.

7) Emura S, Okumura $T$ and Chen H. Scanning electron microscopic study of the tongue in the peregrine falcon and common kestrel. Okajimas Folia Anat Jpn 2008b; 85:11-15.

8) Emura S, Okumura T and Chen H. SEM studies on the connective tissue cores of the lingual papillae of the northern goshawk ( $A c$ cipiter gentilis) (in Japanese). Acta Anatomica Nipponica 2008c; 83:77-80.

9) Emura S, Tamada A, Hayakawa D, Chen H and Shoumura S. SEM study on the dorsal lingual surface of the northern fur seal, Callorhinus ursinus (in Japanese). Mammalian Science 2001; 41: 187-194.

10) Homberger DG and Brush AH. Functional-morphological and biochemical correlations of the keratinized structures in the 
African Grey Parrot, Psittacus erithacus (Aves). Zoomorphology 1986; 106:103-114.

11) Iwasaki $S$, Asami $T$ and Chiba A. Ultrastructural study of the keratinisation of the dorsal epithelium of the tongue of middendorff's bean goose, Anser fabalis middendorfii (Anseres, Antidae). Anat Rec 1997; 247:147-163.

12) Iwasaki S and Kobayashi K. Scanning and transmission electron microscopical studies on the lingual dorsal epithelium of chickens. Acta Anat Nippon 1986; 61:83-96.

13) Jackowiak H. Scanning electron microscopy study of the lingual papillae in the European mole (Talpa europea, L., Talpidae). Anat
Histol Embryol 2006; 35:190-195.

14) Jackowiak H, Andrzejewski W and Godynicki S. Light and scanning electron microscopic study of the tongue in the cormorant Phalacrocorax carbo (Phalacrocoracidae, Aves). Zoological Science 2006; 23:161-167.

15) Jackowiak H and Godynicki S. The scanning electron microscopic study of lingual papillae in the silver fox (Vulpes vulpes fulva, Desmarest, 1820). Ann Anat 2004; 186:179-183.

16) Jackowiak H and Godynicki S. Light and scanning electron microscopic study of the tongue in the white tailed eagle (Haliaeetus albicilla, Accipitridae, Aves). Ann Anat 2005; 187:197-205. 